\title{
EFFECT OF NUTRIENT DENSITY AND FEED FORM ON PRODUCTIVE PERFORMANCE AND BLOOD PARAMETERS OF BROILER CHICKENS
}

Ismail, F. S. A.; Kh. El. Sherif; M. R. EL-Gogary and S. A. Tuama

Department of poultry production, Faculty of Agriculture, Mansoura, University, 35516, Egypt

Corresponding Author : M.R. El- Gogary, Department of poultry production, Faculty of Agriculture, Mansoura, University ,35516,Egypt

\begin{abstract}
A study was conducted to evaluate the effect of nutrient density and feed form on productive performance and blood parameters of broiler chickens. Two hundred Arbor Acres day-old broiler chicks were divided into five dietary nutrient density groups and two feed forms (mash and pellets). Experimental diets were formulated to contain nutrients recommended by NRC (control), two high levels (H1, H2) and two low levels (L1, L2) from metabolizable energy, crude protein and amino acids (methionine and lysine). Feeding the low nutrient density diets (L1, L2) led to significantly lower feed intake and produced significantly better means of live body weight, body weight gain and feed conversion ratio as compared to other groups. Birds fed on the mash diets consumed less fed exhibited better feed conversion ratio compared with those fed the pellet diets. There were no significant effect of nutrient density on plasma level of glucose, total protein and albumin of broiler chicks. However, plasma activity of transaminases (ALT and AST) increased significantly $(\mathrm{P} \leq 0.05)$ in response to feeding the low levels of nutrient density (L1, L2). There were no significant effects of feed form on plasma level of total protein, albumin or activity of ALT and AST in plasma while, birds fed the mash diets displayed significantly higher $(\mathrm{P} \leq 0.05)$ plasma glucose concentration compared with those fed the pelleted diets. There were no significant effects of nutrient density on plasma level of total lipids, triglycerides, cholesterol, high- density lipoprotein (HDL) and low- density lipoprotein (LDL). No significant effects were observed of feed form on plasma level of total lipids, triglycerides, cholesterol, HDL and LDL. Thus, it can be concluded that it is possible to reduce dietary nutrient density for broiler chicks without any detrimental impact on their growth performance or blood parameters.
\end{abstract}

Keywords: broilers, feed form, energy, proteins, amino acids, blood parameters

\section{INTRODUCTION}

Dietary nutrient density is one of several nutritional factors that has a significant impact on the growth and health of broilers, which in turn affect the economics of broiler production (Campbell et al., 1988). Another important factor affecting the performance and health of broilers is the physical form of diets. Today, the majority of broiler feed is processed as crumbles or pellets, while mash rations are still fed in areas where pelleting equipment is unavailable or considered uneconomical. Physical form has been reported to affect broiler growth performance. (Greenwood et al., 2005; Lemme et al., 2006)

Dietary nutrient density and the physical form of diet are two important factors that can affect broiler uniformity (Scott, 2002). Changing the level of nutrient density compared with the nutritionally- adequate diets can be used as a means for approaching the ideal protein concept (Baker and Han, 1994) to provide a precise ratio of amino acids and minimize nitrogen excretion. The rapid growth rate of the present-day broilers necessitates increased amounts of all nutrients and energy on a daily basis, but these demands for different nutrients may vary considerably. Amino acid requirements increase proportionally faster than do energy requirements; thus, a higher amino acid to energy ratio is required in the newly developed faster growing strains of broilers. (Gous., 2010). Therefore, the purpose of the present study was to investigate the effects of feeding different nutritional density levels of energy, protein and amino acid (Meth. and Lys) and two feed forms (mash and pellet), and their interactions on broiler chickens performance.

\section{MATERIALS AND METHODS}

The experimental work of the present study was carried out from July to August, 2015 in the Poultry Production Farm; Qalabsho Center of Agricultural Research and Experiments, Faculty of Agriculture, Mansoura University, Egypt The aim of study was to evaluate the effect of feeding different nutritional density and diets with two forms (mash or pellets) on growth performance, some blood parameters, lipid peroxidation and fatty acid profile in broiler chickens.

\section{Birds, Management and Experimental Design:}

Arbor Acres broiler chickens $(n=200)$, one-dayold with an average body weight of $37 \mathrm{~g}$, were divided into ten treatment groups, each of which included four replicates (cages). A completely randomized block design with a $5 \times 2$ factorial arrangement of treatments was used; 5 nutritional densities and two feed forms (mash and pellets). Experimentally diets were formulated to contain nutrient requirements recommend by NRC., 1994 (control), two high levels (H1, H2) and two low levels (L1, L2) from metabolizable energy (ME), crude protein and amino acids (methionine and lysine) that were fed from 1 to $49 \mathrm{~d}$ of age. The estimated means of $\mathrm{ME}$ of the experimental diets were $3200,3345,3497,3050$ and $2900 \mathrm{kcal} / \mathrm{kg}$ for both the starter and growing periods. Crude protein contents of the experimental starter diets were $23 \%, 24.08 \%$, $25.17 \%, 21.93 \%$, and $20.85 \%$. In the grower diets, these levels were $19 \%, 19.89 \%, 20.79 \%, 18.12 \%$, and $17.22 \%$, respectively. Lysine and methionine levels in 
the starter experimental diets were 1.1 and $0.52 \%, 1.15$ and $0.55 \%, 1.19$ and $0.59 \%, 1.06$ and $0.49 \%$ and 1.03 and $0.46 \%$, respectively. These levels of the two amino acids were 1.0 and $0.57 \%, 1.04$ and $0.59 \%, 1.07$ and $0.61 \%, 0.96$ and $0.54 \%$ and 0.90 and $0.50 \%$ of grower diets, respectively. All the experimental diets were formulated to have similar calories/ CP ratios.
Each replicate group of chickens was reared in a separate compartment in a battery cage measuring $70 \mathrm{~cm}$ length, $60 \mathrm{~cm}$ width and $40 \mathrm{~cm}$ height. Thus the cage floor area was $0.42 \mathrm{~m}^{2}(70 \times 60 \mathrm{~cm})$. The number of birds kept in each cage was 5 birds. Feed and water (via nipple drinkers) were provided freely. The composition and calculated analysis of the experimental diets are shown in Table 1.

Table 1: Composition and calculated analysis of the experimental diets:

\begin{tabular}{|c|c|c|c|c|c|c|c|c|c|c|}
\hline \multirow{2}{*}{ Ingredients (\%) } & \multicolumn{5}{|c|}{ Starter diets } & \multicolumn{5}{|c|}{ Grower diets } \\
\hline & control & H1 & H2 & L1 & $\mathbf{L} 2$ & Control & H1 & H2 & L1 & $\mathbf{L 2}$ \\
\hline Yellow corn & 62.87 & 58.70 & 55.00 & 62.7 & 62.10 & 73.45 & 69.50 & 67.00 & 71.46 & 67.30 \\
\hline Soybean meal $44 \% \mathrm{CP}$ & 13.03 & 11.95 & 9.6 & 21.43 & 30.82 & 6.41 & 5.80 & 2.60 & 15.2 & 16.86 \\
\hline Corn gluten meal $60 \% \mathrm{CP}$ & 18.50 & 21.5 & 25.3 & 11.1 & 3.05 & 14.75 & 17.17 & 21.16 & 7.40 & 4.00 \\
\hline Wheat bran & 0.00 & 0.00 & 0.00 & 0.00 & 0.00 & 0.87 & 0.60 & 0.39 & 1.89 & 7.96 \\
\hline Dicalcium Phosphate & 1.80 & 1.8 & 1.8 & 1.75 & 1.70 & 1.34 & 1.34 & 1.36 & 1.25 & 1.20 \\
\hline Limestone & 1.45 & 1.45 & 1.45 & 1.43 & 1.38 & 1.5 & 1.50 & 1.52 & 1.52 & 1.50 \\
\hline DL-m & 0.05 & 0.05 & 0.05 & 0.08 & 0.11 & 0.18 & 0.17 & 0.16 & 0.20 & 0.20 \\
\hline L-Lysir & 0.40 & 0.45 & 0.53 & 0.21 & 0.01 & 0.48 & 0.52 & 0.61 & 0.28 & 0.18 \\
\hline Sodi & 0.30 & 0.30 & 0.30 & 0.30 & 0.30 & 0.30 & 0.30 & 0.30 & 0.30 & 0.30 \\
\hline Vit+Min Premix ${ }^{1}$ & 0.30 & 0.30 & 0.30 & 0.30 & 0.30 & 0.30 & 0.30 & 0.30 & 0.30 & 0.30 \\
\hline Vegetable oil & 1.30 & 3.50 & 5.67 & 0.70 & 0.23 & 0.42 & 2.80 & 4.6 & 0.20 & 0.20 \\
\hline Total & 100 & 100 & 100 & 100 & 100 & 100 & 100 & 100 & 100 & 100 \\
\hline \multicolumn{11}{|c|}{ Calculated analysis (AS-Fed basis, NRC, 1994) } \\
\hline $\mathrm{ME}, \mathrm{kcal} / \mathrm{kg}$ & 3199 & 3340 & 3496 & 3052 & 2901 & 3200 & 3350 & 3450 & 3050 & 2900 \\
\hline $\mathrm{CP}, \%$ & 23 & 24.08 & 25.017 & 21.93 & 20.85 & 19 & 19.89 & 20.79 & 18.12 & 17.22 \\
\hline Calci & 1.0 & 0.99 & 0.99 & 1.0 & 1.0 & 0.90 & 0.90 & 0.90 & 0.91 & 0.91 \\
\hline Non-phytate P \% & 0.45 & 0.45 & 0.44 & 0.45 & 0.46 & 0.35 & 0.35 & 0.35 & 0.35 & 0.35 \\
\hline Methionine, $\%$ & 0.52 & 0.55 & 0.59 & 0.49 & 0.46 & 0.57 & 0.59 & 0.61 & 0.54 & 0.50 \\
\hline Meth, +Cys, (TSAA, \%) & 0.92 & 0.97 & 1.03 & 0.87 & 0.81 & 0.91 & 0.94 & 0.98 & 0.85 & 0.81 \\
\hline Lysine, $\%$ & 1.1 & 1.15 & 1.19 & 1.06 & 1.03 & 1.0 & 1.04 & 1.07 & 0.96 & 0.90 \\
\hline Arginine $\%$ & 0.98 & 0.99 & 0.97 & 1.11 & 1.26 & 0.76 & 0.76 & 0.73 & 0.90 & 0.94 \\
\hline
\end{tabular}

Premix provided the following per kilogram of diet: Vit.A (retinyl acetate), $2654 \mu \mathrm{g}$; Vit.D3 (cholecalciferol), $125 \mu \mathrm{g}$; Vit.E (dl-atocopheryl acetate), $9.9 \mathrm{mg}$; Vit.K3 (menadionedimethylpyrimidinol), $1.7 \mathrm{mg}$; thiamin mononitrate, $1.6 \mathrm{mg}$; cyanocobalamin, $16.7 \mu \mathrm{g}$; riboflavin, $5.3 \mathrm{mg}$; niacin (niacinamide), $36 \mathrm{mg}$; calcium pantothenate, $13 \mathrm{mg}$; folic acid, $0.8 \mathrm{mg}$; d-biotin, $0.1 \mathrm{mg}$; Fe (iron sulphate monohydrate), $50 \mathrm{mg}$; $\mathrm{Cu}$ (copper sulphate pentahydrate), $12 \mathrm{mg}$; I (calcium iodate), $0.9 \mathrm{mg}$; Zn (zinc oxide), $50 \mathrm{mg}$; Mn (manganous oxide), $60 \mathrm{mg}$; Se (sodium selenite), $0.2 \mathrm{mg}$; Co (cobalt sulphate), $0.2 \mathrm{mg}$.

\section{Performance of broiler chicks:}

Live body weight (BW); feed intake (FI) and body weight gain (BWG) of broiler chickens were measured weekly throughout the experimental period, then feed conversion ratio (FCR) was calculated ( $\mathrm{g}$ feed: $\mathrm{g}$ gain). Birds of each replication were weighed to the nearest gram in the early morning before receiving any feed or water at the start of study (day- old) ant at weekly intervals thereafter. Mortalities and health status were visually observed and recorded daily throughout the entire experimental period.

Blood sampling and biochemical analysis:

At 7 weeks of age, Four birds from each treatment (a bird per replication) were chosen, slaughtered and blood samples were collected in heparinized tubes then centrifuged at $4000 \mathrm{rpm}$ for 15 min. and the plasma obtained was stored at $-20^{\circ} \mathrm{C}$ until analysis. Plasma samples were tested colorimetrically using commercial kits, according to the procedures outlined by the manufactures, for determination of glucose (Trinder, 1969) total protein (Doumas et al., 1981), albumin (Doumas et al., 1971), total lipids (Frings and Dunn, 1970), triglycerides (Fossati and
Prencipe, 1982), cholesterol (Allain et al., 1974), high density lipoprotein (HDL) and low density lipoprotein (LDL) (Myers et al,. 1994). Liver function tests of alanine aminotransferase (ALT) and aspartate aminotransferase (AST) were determined (Reitman and Frankle, 1957).

Statistical analysis:

Statistical analysis for the obtained data was performed by two-way analysis of variance using the method of least square analysis of Co-variance (SAS, 1996). Duncan's multiple range tests was used to separate significant differences among means of the tested variables (Duncan, 1955).

\section{RESULTS AND DISCUSSION}

\section{Growth performance of broiler chicks: \\ Live body weight:}

Table 2 shows the effects of nutrient density and feed form on live body weight (LBW) of broiler chicks during the whole experimental period (one to 49 days of age). Dietary level of nutrients had a significant effect on LBW of broiler chicks at different ages. The control 
group had the heaviest LBW until the $7^{\text {th }}$ week of age compared with other experimental groups, except at the last week of experimental period where the low density group (L2) achieved significantly heavier LBW than the other groups. On the other hand, feed form had insignificant effect on the LBW of broiler chicken at whole experimental period. The present results are in agreement with the findings of Cheng et al., (1997), who found that an increase in the protein level of diets may increase broiler heat production concomitant with protein digestion, absorption, and metabolism. Also, the excretion of surplus amino acids (AA) from the body in the form of uric acid may cause birds to expend more energy and thereby produce more heat. This may exacerbate the growth depression that occurs in hot and humid conditions. Similarly, other researcher Abbasi et al., (2014) indicated that it is possible to reduce dietary CP level up to $10 \%$ after the starter period without any detrimental impact on growth performance. Also, dietary nutrient density and feed form interactions had no effect $(\mathrm{P}>0.05)$ on LBW of broilers at different ages. However, Brickett et al., (2007) found that nutrient density had a significant interaction with feed form for many of the performance criteria studied; nutrient density by feed form interaction was significant on live body weight at ages examined. They indicated that LBW of broilers was not affected by nutrient density when diets were fed in crumble or pellets form. In contrast, they also reported that LBW of birds decreased with reduced nutrient density when diets were in mash form.

\section{Body weight gain:}

The effects of nutrient density and feed form on body weight gain (BWG) of broiler chicks from one to 49 days of age are shown in Table 3 . It was observed that nutrient density did not significantly influence $(\mathrm{P}>0.05)$ BWG of broiler chicks for the periods of 1421, 21-28 and 28-35 days of age; however, nutrient density significantly affected BWG of broiler chickens for the remaining periods. The BWG of broilers fed the high nutrient density diets (H1, H2) were significantly lower compared with the control group but feeding the low nutrient density diets (L1, L2), produced significantly higher means of $\mathrm{BWG}$ as compared to the other treatments. Our result is in agreement with Ferguson et al., (1998) who reported that reducing CP content of the starter diet by $1-6 \%(16 \mathrm{~g} / \mathrm{kg})$ decreased BWG of broilers by $3-5 \%$ and hence, depressed body weight at 21 days of age.

Table 2: Effects of nutrient density and feed form on live body weight (LBW; kg) of broiler chicks from one to 49 days of age

\begin{tabular}{|c|c|c|c|c|c|c|c|c|}
\hline Main effects: & $\begin{array}{c}\text { LBW } \\
\text { 1-d-old }\end{array}$ & $\begin{array}{c}\text { LBW } \\
\text { 7-d-old }\end{array}$ & $\begin{array}{c}\text { LBW } \\
\text { 14-d-old }\end{array}$ & $\begin{array}{c}\text { LBW } \\
\text { 21-d-old } \\
\end{array}$ & $\begin{array}{c}\text { LBW } \\
\text { 28-d-old }\end{array}$ & $\begin{array}{c}\text { LBW } \\
\text { 35-d-old }\end{array}$ & $\begin{array}{c}\text { LBW } \\
\text { 42-d-old } \\
\end{array}$ & $\begin{array}{c}\text { LBW } \\
\text { 49-d-old }\end{array}$ \\
\hline \multicolumn{9}{|c|}{ Nutrient density (A) } \\
\hline Control( A1) & 0.0370 & $0.1006^{\mathrm{a}}$ & $0.2463^{\mathrm{a}}$ & 0.4666 & $0.7622^{\mathrm{a}}$ & $1.1228^{\mathrm{a}}$ & $1.5340^{\mathrm{a}}$ & $1.9303^{\mathrm{ab}}$ \\
\hline $\mathrm{H} 1(\mathrm{~A} 2)$ & 0.0380 & $0.0735^{\mathrm{b}}$ & $0.1269^{\mathrm{b}}$ & 0.2771 & $0.5695^{\mathrm{b}}$ & $0.9080^{\mathrm{b}}$ & $1.3724^{\mathrm{b}}$ & $1.8510^{\mathrm{b}}$ \\
\hline $\mathrm{H} 2(\mathrm{~A} 3)$ & 0.0371 & $0.0693^{\mathrm{b}}$ & $0.1081^{\mathrm{c}}$ & 0.2608 & $0.5033^{\mathrm{b}}$ & $0.9201^{\mathrm{b}}$ & $1.1858^{\mathrm{c}}$ & $1.5710^{\mathrm{c}}$ \\
\hline L1( A4) & 0.0377 & $0.0741^{\mathrm{b}}$ & $0.1282^{b}$ & 0.4238 & $0.5416^{\mathrm{b}}$ & $0.9201^{\mathrm{b}}$ & $1.2915^{\mathrm{bc}}$ & $1.9302^{\mathrm{ab}}$ \\
\hline L2( A5) & 0.0373 & $0.0732^{b}$ & $0.1157^{\mathrm{bc}}$ & 0.2611 & $0.5342^{b}$ & $0.9045^{\mathrm{b}}$ & $1.3526^{\mathrm{b}}$ & $1.9715^{\mathrm{a}}$ \\
\hline Pooled SEM & 0.0004 & 0.0016 & 0.0058 & 0.0735 & 0.0244 & 0.0436 & 0.0373 & 0.0271 \\
\hline Significance & NS & $*$ & $*$ & NS & $*$ & $*$ & $*$ & $*$ \\
\hline \multicolumn{9}{|l|}{ Feed form (B) } \\
\hline $\operatorname{Mash}(B 1)$ & 0.0371 & 0.0781 & 0.1488 & \multirow{3}{*}{$\begin{array}{l}0.3708 \\
0.3049 \\
0.0464\end{array}$} & 0.5938 & 0.9910 & 1.3682 & 1.8496 \\
\hline Pellet (B2) & 0.0377 & 0.0781 & 0.1412 & & 0.5705 & 0.9192 & 1.3264 & 1.8520 \\
\hline Pooled SEM & 0.0003 & 0.001 & 0.0037 & & 0.0154 & 0.0276 & 0.0236 & 0.0172 \\
\hline Significance & NS & NS & NS & NS & NS & NS & NS & NS \\
\hline \multicolumn{9}{|l|}{$\mathrm{AB}$ Interaction } \\
\hline $\mathrm{A} 1 * \mathrm{~B} 1$ & 0.0382 & 0.1016 & 0.2520 & 0.4730 & 0.7663 & 1.1592 & 1.5460 & 1.8965 \\
\hline $\mathrm{A} 1 * \mathrm{~B} 2$ & $0 . .0365$ & 0.0996 & 0.2406 & 0.4602 & 0.7581 & 1.0865 & 1.5221 & 1.9641 \\
\hline $\mathrm{A} 2 * \mathrm{~B} 1$ & 0.0376 & 0.0732 & 0.1380 & 0.3014 & 0.5913 & 0.9201 & 1.3841 & 1.8379 \\
\hline $\mathrm{A} 2 * \mathrm{~B} 2$ & 0.0382 & 0.0738 & 0.1158 & 0.2528 & 0.5477 & 0.8960 & 1.3607 & 1.8641 \\
\hline $\mathrm{A} 3 * \mathrm{~B} 1$ & 0.0366 & 0.0700 & 0.1060 & 0.2413 & 0.5118 & 1.0118 & 1.2392 & 1.6408 \\
\hline $\mathrm{A} 3 * \mathrm{~B} 2$ & 0.0377 & 0.0687 & 0.1102 & 0.2804 & 0.4947 & 0.8283 & 1.1325 & 1.5012 \\
\hline $\mathrm{A} 4 * \mathrm{~B} 1$ & 0.0371 & 0.0738 & 0.1287 & 0.5736 & 0.5485 & 0.9245 & 1.3015 & 1.9146 \\
\hline $\mathrm{A} 4 * \mathrm{~B} 2$ & 0.0381 & 0.0744 & 0.1276 & 0.2739 & 0.5348 & 0.9157 & 1.2815 & 1.9459 \\
\hline $\mathrm{A} 5 * \mathrm{~B} 1$ & 0.0377 & 0.0722 & 0.1194 & 0.2649 & 0.5512 & 0.9393 & 1.3701 & 1.9582 \\
\hline $\mathrm{A} 5 * \mathrm{~B} 2$ & 0.0371 & 0.0742 & 0.1120 & 0.2573 & 0.5172 & 0.8698 & 1.3352 & 1.9849 \\
\hline Pooled SEM & 0.0005 & 0.0023 & 0.0083 & 0.1039 & 0.0346 & 0.0617 & 0.0527 & 0.0384 \\
\hline Significance & NS & NS & NS & NS & NS & NS & NS & NS \\
\hline
\end{tabular}

${ }_{\text {a-c }}$ In each of the main effects, means in the same column with different superscripts differ significantly $(\mathbf{P} \leq \mathbf{0 . 0 5 )}$. 
Table 3: Effects of nutrient density and feed form on body weight gain (BWG; kg) of broiler chicks from one to 49 days of age

\begin{tabular}{|c|c|c|c|c|c|c|c|c|}
\hline Main effects: & $\begin{array}{l}\text { BWG } \\
1^{\text {st }} \mathbf{w k}\end{array}$ & $\begin{array}{l}\text { BWG } \\
2^{\text {nd }} w k\end{array}$ & $\begin{array}{l}\text { BWG } \\
3^{\text {rd }} \text { Wk }\end{array}$ & $\begin{array}{l}\text { BWG } \\
4^{\text {th }} \text { wk }\end{array}$ & $\begin{array}{l}\text { BWG } \\
5^{\text {th }} \text { wk }\end{array}$ & $\begin{array}{l}\text { BWG } \\
6^{\text {th }} \text { wk }\end{array}$ & $\begin{array}{l}\text { BWG } \\
7^{\text {th }} \text { wk }\end{array}$ & Total gain \\
\hline \multicolumn{9}{|c|}{ Nutrient density (A) } \\
\hline Control ( A1) & $0.0633^{\mathrm{a}}$ & $0.1457^{\mathrm{a}}$ & 0.2203 & 0.2955 & 0.3606 & $0.4111^{\mathrm{ab}}$ & $0.3962^{\mathrm{b}}$ & $1.8511^{\mathrm{ab}}$ \\
\hline $\mathrm{H} 1(\mathrm{~A} 2)$ & $0.0356^{\mathrm{b}}$ & $0.0534^{\mathrm{b}}$ & 0.1501 & 0.2924 & 0.3385 & $0.4644^{\mathrm{a}}$ & $0.4785^{\mathrm{b}}$ & $1.8131^{\mathrm{b}}$ \\
\hline $\mathrm{H} 2(\mathrm{~A} 3)$ & $0.0322^{\mathrm{b}}$ & $0.0387^{\mathrm{b}}$ & 0.1527 & 0.2424 & 0.4168 & $0.2657^{\mathrm{b}}$ & $0.3851^{\mathrm{b}}$ & $1.5339^{c}$ \\
\hline L1( A4) & $0.0365^{\mathrm{b}}$ & $0.0541^{\mathrm{b}}$ & 0.2956 & 0.1178 & 0.3784 & $0.3713^{\mathrm{ab}}$ & $0.6387^{\mathrm{a}}$ & $1.8926^{\mathrm{ab}}$ \\
\hline L2( A5) & $0.0359^{\mathrm{b}}$ & $0.0424^{\mathrm{b}}$ & 0.1453 & 0.2731 & 0.3703 & $0.4480^{\mathrm{a}}$ & $0.6188^{\mathrm{a}}$ & $1.9342^{\mathrm{a}}$ \\
\hline Pooled SEM & 0.0015 & 0.0053 & 0.0704 & 0.0657 & 0.0355 & 0.0455 & 0.0410 & 0.0291 \\
\hline Significance & $*$ & * & NS & NS & NS & $*$ & $*$ & $*$ \\
\hline \multicolumn{9}{|l|}{ Feed form (B) } \\
\hline $\operatorname{Mash}(\mathrm{B} 1)$ & 0.0410 & $0.0706^{\mathrm{A}}$ & 0.2220 & 0.2230 & 0.3971 & 0.3772 & 0.4814 & 1.8124 \\
\hline Pellet (B2) & 0.0405 & 0.0631 & 0.1636 & 0.2655 & 0.3487 & 0.4071 & 0.5256 & 1.7975 \\
\hline Pooled SEM & 0.001 & 0.0034 & 0.0445 & 0.0415 & 0.0225 & 0.0287 & 0.0259 & 0.0184 \\
\hline Significance & NS & NS & NS & NS & NS & NS & NS & NS \\
\hline \multicolumn{9}{|l|}{$\mathrm{AB}$ Interaction } \\
\hline $\mathrm{A} 1 * \mathrm{~B} 1$ & 0.0647 & 0.1504 & 0.2210 & 0.2933 & 0.3929 & 0.3867 & 0.3505 & 1.8596 \\
\hline $\mathrm{A} 1 * \mathrm{~B} 2$ & 0.0622 & 0.1410 & 0.2196 & 0.2978 & 0.3284 & 0.4356 & 0.4420 & 1.8425 \\
\hline $\mathrm{A} 2 * \mathrm{~B} 1$ & 0.0356 & 0.0648 & 0.1633 & 0.2899 & 0.3287 & 0.4640 & 0.4537 & 1.8003 \\
\hline $\mathrm{A} 2 * \mathrm{~B} 2$ & 0.0356 & 0.0420 & 0.1369 & 0.2949 & 0.3482 & 0.4647 & 0.5034 & 1.8259 \\
\hline $\mathrm{A} 3 * \mathrm{~B} 1$ & 0.0335 & 0.0360 & 0.1352 & 0.2705 & 0.5000 & 0.2274 & 0.4016 & 1.6043 \\
\hline $\mathrm{A} 3 * \mathrm{~B} 2$ & 0.0310 & 0.0415 & 0.1702 & 0.2143 & 0.3336 & 0.3041 & 0.3687 & 1.4635 \\
\hline $\mathrm{A} 4 * \mathrm{~B} 1$ & 0.0367 & 0.0549 & 0.4449 & 0.0251 & 0.3759 & 0.3770 & 0.6131 & 1.8775 \\
\hline $\mathrm{A} 4 * \mathrm{~B} 2$ & 0.0363 & 0.0532 & 0.1463 & 0.2608 & 0.3809 & 0.3657 & 0.6644 & 1.9078 \\
\hline $\mathrm{A} 5 * \mathrm{~B} 1$ & 0.0346 & 0.0472 & 0.1454 & 0.2863 & 0.3880 & 0.4308 & 0.5881 & 1.9205 \\
\hline $\mathrm{A} 5 * \mathrm{~B} 2$ & 0.0372 & 0.0377 & 0.1453 & 0.2599 & 0.3526 & 0.4653 & 0.6496 & 1.9478 \\
\hline Pooled SEM & 0.0021 & 0.0076 & 0.0996 & 0.0929 & 0.0503 & 0.0643 & 0.0580 & 0.0412 \\
\hline Significance & NS & NS & NS & NS & NS & NS & NS & NS \\
\hline
\end{tabular}

${ }^{a-c}$ : In each of the main effects, means in the same column with different superscripts differ significantly $(\mathbf{P} \leq \mathbf{0 . 0 5})$

\section{Feed intake:}

The effects of nutrient density and feed form on feed intake (FI) of broiler chicks from one to 49 days of age are shown in Table 4. Nutrient density had insignificant effect on FI of birds during the periods of 14 - 21 and 42 - 49 days of age. However, control group consumed more feed during the periods from of one to 7, 7-14, 21-28 and the whole experimental period compared of other groups. On the other hand, feed form had no effect $(\mathrm{P}>0.05)$ on FI of chicks during the periods of one to $7,7-14,14-21,21-28,28-35$ and 35 to 42 days of age but feeding the mash diets significantly reduced $(\mathrm{P} \leq 0.05)$ FI of birds during the periods of 42 - 49 and whole experimental period compared with birds fed the pellet diets. This result is in agreement with the suggestion of Richards (2003) that broiler chickens selected for rapid weight gain do not properly regulate voluntary feed intake according to dietary energy level; thus they display compulsive appetite and excessive fat accumulation.

Feed conversion ratio:

The effects of nutrient density and feed form on feed conversion ratio (FCR) of broiler chicks from one to 49 days of age are given in Table 5. Dietary nutrient density had no significant effect $(\mathrm{P}>0.05)$ on FCR of chicks during the periods of $14-21,21-28,28-35$ and 35- 42 days of age. However, control group had the best significant FCR of broiler chickens at the periods of one to 7 and 7 to 14 compared to other groups. On the contrary, feeding lower nutrient density (L2) produced the best in FCR of birds at the periods 42-49 and whole experimental period as compared to other groups. On the other hand, feed form had no effect $(\mathrm{P}>0.05)$ on FCR of broiler chicks during the periods of one to 7, 7$14,14-21,28-35,35-42$ and 42-49 days of age but the mash diets significantly improved $(\mathrm{P} \leq 0.05)$ FCR of birds during the periods of 21-28 and whole experimental period compared with these fed the pelleted diets. In addition, insignificant interactions $(\mathrm{P}>0.05)$ were observed between nutrient density and feed form on FCR of broilers for all age intervals investigated except the periods of 21-28 days old and whole experimental period. Similarly, Kermanshahi et al., (2011) had reported that broiler chickens fed diets containing $15 \%$ more $\mathrm{CP}$ than NRC recommendation had inferior FCR in overall period of study (days 1-21) when compared with those of broiler chickens fed diets containing $15 \%$ less CP and NRC recommendation.

\section{Blood plasma parameters: -}

The effect of nutrient density and feed form on plasma concentrations of glucose, total protein, albumin and activity of plasma ALT and AST are presented in Table 6. There were no significant effects of nutrient density on levels of plasma glucose, total protein and albumin of broiler chicks. However, activity of plasma ALT and AST levels increased significantly $(\mathrm{P} \leq 0.05)$ in response to low levels of nutrient density $(\mathrm{L} 1, \mathrm{~L} 2)$. No significant effects of feed form on plasma level of total protein, albumin or activity of ALT and AST in blood plasma while, the mash diets led to a significant increase in $(\mathrm{P} \leq 0.05)$ plasma levels of glucose 
concentration compared with the pelleted diets. Insignificant interactions $(\mathrm{P}>0.05)$ were observed between nutrient density and feed form on plasma level of glucose, total protein and albumin or on activity of plasma ALT and AST of broiler chickens. The present result is in agreement with that of Corduk et al., (2007), who found that dietary ME density had no significant effect on the serum triglycerides, cholesterol and glucose concentrations of the broiler chickens.

Table 4: Effects of nutrient density and feed form on feed intake (FI; kg) of broiler chicks from one to 49 days of age

\begin{tabular}{|c|c|c|c|c|c|c|c|c|}
\hline Main effects: & FI $1^{\text {st }}$ wk & FI $2^{\text {nd }} w k$ & FI 3 ${ }^{\text {rd }}$ wk & FI $4^{\text {th }}$ wk & FI $5^{\text {th }} w k$ & FI $6^{\text {th }} w k$ & FI $7^{\text {th }}$ wk & Total FI \\
\hline \multicolumn{9}{|c|}{ Nutrient density (A) } \\
\hline Control( A1) & $0.1041^{\mathrm{a}}$ & $0.2112^{\mathrm{a}}$ & 0.2733 & $0.5296^{\mathrm{a}}$ & $0.7466^{\mathrm{a}}$ & $0.8993^{\mathrm{c}}$ & 1.1500 & $4.0181^{\mathrm{a}}$ \\
\hline $\mathrm{H} 1(\mathrm{~A} 2)$ & $0.0641^{\mathrm{b}}$ & $0.1555^{\mathrm{b}}$ & 0.2386 & $0.4578^{\mathrm{b}}$ & $0.6673^{\mathrm{b}}$ & $1.0292^{\mathrm{a}}$ & 1.2063 & $3.8832^{\mathrm{ab}}$ \\
\hline $\mathrm{H} 2(\mathrm{~A} 3)$ & $0.0935^{\mathrm{a}}$ & $0.1521^{\mathrm{b}}$ & 0.2432 & $0.4760^{\mathrm{ab}}$ & $0.6641^{\mathrm{b}}$ & $0.9180^{\mathrm{c}}$ & 1.1152 & $3.7560^{\mathrm{b}}$ \\
\hline L1( A4) & $0.0940^{\mathrm{a}}$ & $0.1457^{\mathrm{b}}$ & 0.2570 & $0.4406^{\mathrm{b}}$ & $0.7116^{\mathrm{ab}}$ & $0.9528^{\mathrm{bc}}$ & 1.1757 & $3.8715^{\mathrm{ab}}$ \\
\hline L2( A5) & $0.0895^{\mathrm{a}}$ & $0.1155^{\mathrm{c}}$ & 0.2560 & $0.4665^{\mathrm{b}}$ & $0.7098^{\mathrm{ab}}$ & $0.9947^{\mathrm{ab}}$ & 1.1355 & $3.8573^{\mathrm{b}}$ \\
\hline Pooled SEM & 0.0055 & 0.0041 & 0.0083 & 0.0192 & 0.0169 & 0.0213 & 0.0337 & 0.0503 \\
\hline Significance & $*$ & $* *$ & NS & $*$ & $*$ & $* *$ & NS & $*$ \\
\hline \multicolumn{9}{|l|}{ Feed form (B) } \\
\hline $\operatorname{Mash}(\mathrm{B} 1)$ & 0.0862 & 0.1550 & 0.2558 & 0.4584 & 0.7029 & 0.9549 & $1.1173^{\mathrm{b}}$ & $3.8168^{\mathrm{b}}$ \\
\hline Pellet (B2) & 0.0918 & 0.1570 & 0.2514 & 0.4898 & 0.6969 & 0.9628 & $1.1958^{\mathrm{a}}$ & $3.9377^{\mathrm{a}}$ \\
\hline Pooled SEM & 0.0035 & 0.0026 & 0.0052 & 0.0121 & 0.0107 & 0.0135 & 0.0213 & 0.0318 \\
\hline Significance & NS & NS & NS & NS & NS & NS & $*$ & $*$ \\
\hline \multicolumn{9}{|l|}{$\mathrm{AB}$ Interaction } \\
\hline $\mathrm{A} 1 * \mathrm{~B} 1$ & 0.1067 & 0.2175 & 0.2840 & 0.5467 & 0.7657 & 0.8930 & 1.0422 & 3.9625 \\
\hline $\mathrm{A} 1 * \mathrm{~B} 2$ & 0.1015 & 0.2050 & 0.2627 & 0.5125 & 0.7275 & 0.9057 & 1.2577 & 4.0737 \\
\hline $\mathrm{A} 2 * \mathrm{~B} 1$ & 0.0610 & 0.1612 & 0.2395 & 0.4477 & 0.6812 & 1.0212 & 1.1827 & 3.8552 \\
\hline $\mathrm{A} 2 * \mathrm{~B} 2$ & 0.0672 & 0.1497 & 0.2393 & 0.4680 & 0.6535 & 1.0372 & 1.2300 & 3.9112 \\
\hline $\mathrm{A} 3 * \mathrm{~B} 1$ & 0.0827 & 0.1370 & 0.2480 & 0.4312 & 0.5915 & 0.9242 & 1.1370 & 3.6347 \\
\hline $\mathrm{A} 3 * \mathrm{~B} 2$ & 0.1042 & 0.1672 & 0.2385 & 0.5207 & 0.7367 & 0.9117 & 1.0935 & 3.8772 \\
\hline $\mathrm{A} 4 * \mathrm{~B} 1$ & 0.0950 & 0.1400 & 0.2442 & 0.3930 & 0.7252 & 1.0082 & 1.1325 & 3.8330 \\
\hline $\mathrm{A} 4 * \mathrm{~B} 2$ & 0.0930 & 0.1515 & 0.2697 & 0.4882 & 0.6980 & 0.8975 & 1.2190 & 3.9100 \\
\hline $\mathrm{A} 5 * \mathrm{~B} 1$ & 0.0857 & 0.1192 & 0.2635 & 0.4735 & 0.7510 & 0.9277 & 0.0920 & 3.7985 \\
\hline $\mathrm{A} 5 * \mathrm{~B} 2$ & 0.0932 & 0.1117 & 0.2485 & 0.4595 & 0.6687 & 0.0617 & 1.1790 & 3.9162 \\
\hline Pooled SEM & 0.008 & 0.006 & 0.012 & 0.027 & 0.024 & 0.030 & 0.048 & 0.071 \\
\hline Significance & NS & $*$ & NS & NS & $*$ & NS & NS & NS \\
\hline
\end{tabular}

Table 5: Effects of nutrient density and feed form on feed conversion ratio (feed: gain) of broiler chicks from one to 49 days of age

\begin{tabular}{|c|c|c|c|c|c|c|c|c|}
\hline Main effects: & FCR $1^{\text {st }}$ wk & FCR 2 ${ }^{\text {nd }}$ wk & FCR3 $^{\text {rd }}$ wk & FCR 4 ${ }^{\text {th }}$ wk & FCR $5^{\text {th }}$ wk & FCR $6^{\text {th }}$ wk & FCR $7^{\text {th }}$ wk & Total FCR \\
\hline \multicolumn{9}{|c|}{ Nutrient density (A) } \\
\hline Control( A1) & $1.6406^{\mathrm{a}}$ & $1.4518^{\mathrm{a}}$ & 1.2496 & 1.8150 & 2.1371 & 2.2862 & $2.9646^{\mathrm{b}}$ & $2.1243^{\mathrm{b}}$ \\
\hline $\mathrm{H} 1(\mathrm{~A} 2)$ & $1.7912^{\mathrm{a}}$ & $3.2292^{\mathrm{b}}$ & 1.6116 & 1.6325 & 1.9992 & 2.2463 & $2.5527^{\mathrm{b}}$ & $2.1458^{\mathrm{b}}$ \\
\hline $\mathrm{H} 2(\mathrm{~A} 3)$ & $3.0207^{\mathrm{b}}$ & $4.0161^{\mathrm{c}}$ & 1.6983 & 2.0745 & 1.7916 & 2.9058 & $2.9083^{\mathrm{b}}$ & $2.4582^{\mathrm{c}}$ \\
\hline L1( A4) & $2.6172^{\mathrm{b}}$ & $2.9017^{\mathrm{b}}$ & 1.7602 & 1.6990 & 1.9385 & 2.9493 & $2.0228^{\mathrm{a}}$ & $2.0471^{\mathrm{ab}}$ \\
\hline L2( A5) & $2.5460^{\mathrm{b}}$ & $2.7903^{b}$ & 1.8223 & 1.7323 & 1.9538 & 2.2366 & $1.9011^{\mathrm{a}}$ & $1.9961^{\mathrm{a}}$ \\
\hline Pooled SEM & 0.2413 & 0.2141 & 0.1601 & 0.1122 & 0.1328 & 02876 & 0.1741 & 0.0361 \\
\hline Significance & $*$ & $*$ & NS & NS & NS & NS & $*$ & $*$ \\
\hline \multicolumn{9}{|l|}{ Feed form (B) } \\
\hline $\operatorname{Mash}(B 1)$ & 2.1898 & 2.7040 & 1.6038 & $1.6649^{\mathrm{a}}$ & 1.8982 & 2.6059 & 2.5031 & $2.1141^{\mathrm{a}}$ \\
\hline Pellet (B2) & 2.4565 & 3.0517 & 1.6530 & $1.9164^{b}$ & 2.0299 & 2.4439 & 2.4368 & $2.1946^{\mathrm{b}}$ \\
\hline Pooled SEM & 0.1526 & 0.1354 & 0.1012 & 0.0710 & 0.0840 & 0.1819 & 0.1101 & 0.0228 \\
\hline Significance & NS & NS & NS & $*$ & NS & NS & NS & $*$ \\
\hline \multicolumn{9}{|l|}{$\mathrm{AB}$ Interaction } \\
\hline $\mathrm{A} 1 * \mathrm{~B} 1$ & 1.6485 & 1.4462 & 1.2927 & 1.9065 & 2.0437 & 2.4777 & 3.0275 & 2.1342 \\
\hline $\mathrm{A} 1 * \mathrm{~B} 2$ & 1.6327 & 1.4575 & 1.2065 & 1.7235 & 2.2305 & 2.0947 & 2.9017 & 2.1145 \\
\hline $\mathrm{A} 2 * \mathrm{~B} 1$ & 1.6945 & 2.8432 & 1.4727 & 1.5597 & 2.0920 & 2.2292 & 2.6185 & 2.1467 \\
\hline $\mathrm{A} 2 * \mathrm{~B} 2$ & 1.8880 & 3.6152 & 1.7505 & 1.7025 & 1.9065 & 2.2635 & 2.4870 & 2.1450 \\
\hline $\mathrm{A} 3 * \mathrm{~B} 1$ & 2.4690 & 3.9720 & 1.9430 & 1.6685 & 1.3627 & 2.7992 & 2.8097 & 2.2647 \\
\hline $\mathrm{A} 3 * \mathrm{~B} 2$ & 3.5725 & 4.0602 & 1.4537 & 2.4805 & 2.2205 & 3.0125 & 3.0070 & 2.6517 \\
\hline $\mathrm{A} 4 * \mathrm{~B} 1$ & 2.6212 & 2.7165 & 1.4777 & 1.5125 & 2.0347 & 3.3690 & 2.1312 & 2.0437 \\
\hline $\mathrm{A} 4 * \mathrm{~B} 2$ & 2.6132 & 3.0870 & 2.0427 & 1.8855 & 1.8422 & 2.5297 & 1.9145 & 2.0505 \\
\hline $\mathrm{A} 5 * \mathrm{~B} 1$ & 2.5160 & 2.5420 & 1.8330 & 1.6775 & 1.9577 & 2.1542 & 1.9285 & 1.9810 \\
\hline $\mathrm{A} 5 * \mathrm{~B} 2$ & 2.5760 & 3.0387 & 1.8117 & 1.7872 & 1.9500 & 2.3190 & 1.8737 & 2.0112 \\
\hline Pooled SEM & 0.3412 & 0.3028 & 0.2264 & 0.1588 & 0.1878 & 0.4068 & 0.2462 & 0.2462 \\
\hline Significance & NS & NS & NS & $*$ & NS & NS & NS & * \\
\hline
\end{tabular}


Blood plasma Lipid profile: The effect of nutrient density and feed form on plasma total lipids, triglycerides, cholesterol, HDL and LDL concentrations are presented in Table 7: There were no significant effect of nutrient density on plasma total lipids, triglycerides, cholesterol, HDL and LDL concentrations. No significant effects of feed form on plasma total lipids, triglycerides, cholesterol, and HDL and LDL concentrations. Insignificant interactions $(\mathrm{P}>0.05)$ were observed between nutrient density and feed form on plasma total lipids, triglycerides, cholesterol, HDL and LDL concentrations of broilers. Similarly, Rosebrough et al., (1999) found that dietary fat addition to diets containing low $\mathrm{CP}$ levels did not decrease lipogenesis to the degree noted when added to a diet containing a higher level of CP.

Table 6: Effects of nutrient density and feed form on some blood plasma parameters of broiler chicks

\begin{tabular}{|c|c|c|c|c|c|}
\hline Main effects: & Glucose (g/dl) & TP (g/dl) & Alb (g/dl) & ALT ( IU/I) & AST ( IU/I) \\
\hline \multicolumn{6}{|l|}{ Nutrient density (A) } \\
\hline Control( A1) & 249.7 & 4.107 & 2.223 & $17.12^{\mathrm{bc}}$ & $52.56^{\mathrm{b}}$ \\
\hline $\mathrm{H} 1(\mathrm{~A} 2)$ & 241.3 & 4.348 & 2.317 & $19.98^{\mathrm{ab}}$ & $62.07^{\mathrm{a}}$ \\
\hline $\mathrm{H} 2(\mathrm{~A} 3)$ & 228.8 & 4.220 & 2.276 & $14.48^{\mathrm{c}}$ & $47.07^{\mathrm{b}}$ \\
\hline L1( A4) & 235.0 & 4.367 & 2.303 & $19.31^{\mathrm{ab}}$ & $62.20^{\mathrm{a}}$ \\
\hline L2( A5) & 235.1 & 4.381 & 2.391 & $20.50^{\mathrm{a}}$ & $63.76^{\mathrm{a}}$ \\
\hline Pooled SEM & 16.83 & 0.107 & 0.061 & 0.996 & 2.682 \\
\hline Significance & NS & NS & NS & $* *$ & $*$ \\
\hline \multicolumn{6}{|l|}{ Feed form (B) } \\
\hline $\operatorname{Mash}(\mathrm{B} 1)$ & $257.7^{\mathrm{a}}$ & 4.286 & 2.281 & 18.45 & 57.30 \\
\hline Pellet (B2) & $218.3^{\mathrm{b}}$ & 4.283 & 2.324 & 18.11 & 57.76 \\
\hline Pooled SEM & 10.64 & 0.0679 & 0.0387 & 0.6303 & 1.696 \\
\hline Significance & $*$ & NS & NS & NS & NS \\
\hline \multicolumn{6}{|l|}{ AB Interaction } \\
\hline $\mathrm{A} 1 * \mathrm{~B} 1$ & 285.2 & 4.007 & 2.190 & 17.75 & 53.15 \\
\hline $\mathrm{A} 1 * \mathrm{~B} 2$ & 214.2 & 4.207 & 2.257 & 16.50 & 51.97 \\
\hline $\mathrm{A} 2 * \mathrm{~B} 1$ & 288.0 & 4.340 & 2.315 & 20.32 & 62.67 \\
\hline $\mathrm{A} 2 * \mathrm{~B} 2$ & 194.7 & 4.357 & 2.320 & 19.65 & 61.47 \\
\hline $\mathrm{A} 3 * \mathrm{~B} 1$ & 230.2 & 4.230 & 2.202 & 14.27 & 45.40 \\
\hline $\mathrm{A} 3 * \mathrm{~B} 2$ & 227.5 & 4.210 & 2.350 & 14.70 & 48.75 \\
\hline $\mathrm{A} 4 * \mathrm{~B} 1$ & 226.0 & 4.345 & 2.305 & 18.90 & 60.52 \\
\hline $\mathrm{A} 4 * \mathrm{~B} 2$ & 244.0 & 4.390 & 2.302 & 19.72 & 63.87 \\
\hline $\mathrm{A} 5^{*} \mathrm{~B} 1$ & 259.0 & 4.510 & 2.392 & 21.02 & 64.77 \\
\hline $\mathrm{A} 5 * \mathrm{~B} 2$ & 211.2 & 4.252 & 2.390 & 19.97 & 62.75 \\
\hline Pooled SEM & 23.8 & 0.152 & 0.086 & 1.409 & 3.794 \\
\hline Significance & NS & NS & NS & NS & NS \\
\hline
\end{tabular}

a-c: In each of the main effects, means in the same column with different superscripts differ significantly (P $\leq 0.05)$.

Table 7: Effects of nutrient density and feed form on blood plasma lipid profile of broiler chicks

\begin{tabular}{|c|c|c|c|c|c|}
\hline Main effects: & TL (mg/dl) & Trig.(mg/dl) & Chol. (mg/dl) & HDL (mg/dl) & LDL (mg/dl) \\
\hline \multicolumn{6}{|c|}{ Nutrient density (A) } \\
\hline Control( A1) & 872.8 & 132.2 & 191.2 & 52.53 & 114.41 \\
\hline $\mathrm{H} 1(\mathrm{~A} 2)$ & 894.9 & 133.3 & 197.2 & 54.53 & 105.91 \\
\hline H2( A3) & 880.6 & 132.7 & 175.5 & 52.10 & 107.93 \\
\hline L1( A4) & 861.5 & 138.4 & 191.5 & 52.56 & 107.77 \\
\hline L2( A5) & 882.7 & 136.8 & 194.1 & 52.91 & 106.00 \\
\hline Pooled SEM & 10.92 & 2.03 & 5.579 & 1.20 & 2.584 \\
\hline Significance & NS & NS & NS & NS & NS \\
\hline \multicolumn{6}{|l|}{ Feed form (B) } \\
\hline $\operatorname{Mash}(B 1)$ & 884.9 & 135.49 & 193.2 & 53.12 & 108.5 \\
\hline Pellet (B2) & 872.1 & 133.95 & 186.7 & 52.73 & 108.2 \\
\hline Pooled SEM & 6.90 & 1.28 & 3.528 & 0.76 & 1.634 \\
\hline Significance & NS & NS & NS & NS & NS \\
\hline \multicolumn{6}{|l|}{ AB Interaction } \\
\hline $\mathrm{A} 1 * \mathrm{~B} 1$ & 872.7 & 134.2 & 195.57 & 53.57 & 116.5 \\
\hline $\mathrm{A} 1 * \mathrm{~B} 2$ & 873.0 & 130.3 & 186.95 & 51.50 & 112.3 \\
\hline $\mathrm{A} 2 * \mathrm{~B} 1$ & 891.3 & 130.4 & 199.52 & 53.62 & 110.1 \\
\hline $\mathrm{A} 2 * \mathrm{~B} 2$ & 898.5 & 136.1 & 194.97 & 55.45 & 101.6 \\
\hline $\mathrm{A} 3 * \mathrm{~B} 1$ & 906.3 & 138.3 & 185.87 & 52.22 & 104.9 \\
\hline $\mathrm{A} 3 * \mathrm{~B} 2$ & 855.0 & 127.0 & 165.30 & 51.98 & 110.9 \\
\hline $\mathrm{A} 4 * \mathrm{~B} 1$ & 860.2 & 136.4 & 187.12 & 52.42 & 105.9 \\
\hline $\mathrm{A} 4 * \mathrm{~B} 2$ & 862.7 & 140.4 & 195.97 & 52.70 & 109.5 \\
\hline $\mathrm{A} 5 * \mathrm{~B} 1$ & 894.3 & 138.0 & 197.97 & 53.77 & 105.2 \\
\hline $\mathrm{A} 5 * \mathrm{~B} 2$ & 871.2 & 135.7 & 190.30 & 52.05 & 106.7 \\
\hline Pooled SEM & 15.44 & 2.87 & 7.890 & 1.70 & 3.655 \\
\hline Significance & NS & NS & NS & NS & NS \\
\hline
\end{tabular}




\section{CONCLUSION}

It can be concluded that using low levels of nutrient density may have a positive effect on productive performance of broiler chickens.

\section{REFERENCES}

Abbasi, M.A., A.H. Mahdavi, A.H. Samie and R.I. Jahanian, 2014. Effects of different levels of dietary crude protein and threonine on performance, humoral immune responses and intestinal morphology of broiler chicks. Brazilian Journal of Poultry Science : 16 (1): 35-44

Allain, C.C..; L.S. Poon; C.S.G. Chan; W. Richmond and P.C. Fu ,1974. Enzymatic determination of total serum cholesterol. Clinical Chemistry, 20: $470-475$.

Baker, D. H. and Y. Han, 1994. Ideal amino acid profile for chicks during the first three weeks post-hatching. Poult. Sci. 73: 1441-1447.

Brickett, K. E.; J. P. Dahiya; H. L. Classen, and S. Gomis, 2007. Influence of dietary nutrient density, feed form, and lighting on growth and meat yield of broiler chickens. Poultry Science 86 (10):2172-2181

Campbell, G. L.; R. E. Salmon and H. L. Classen. 1988. Effect of nutrient density on broiler carcass composition as influenced by age. Nutr. Rep. Int. 37: 973-981.

Cheng, T. K.; M. L. Hamre and C. N. Coon. 1997. Effect of environmental temperature, dietary protein, and energy levels on broiler performance. J. Appl. Poult. Res., 6:1-17.

Corduk, M.; N. Ceylan and F. Ildiz, 2007. Effects of dietary energy density and L-carnitine supplementation on growth performance, carcass traits and blood parameters of broiler chickens. South African Journal of Animal Science, 37 (2): 65- 73 .

Doumas, B.T.; D.D. Bayse ; R.J. Carter; T. Peters and R. Schaffer, 1981. A candidate reference method for determination of total protein in serum. 1 . Development and validation. Clin. Chem., 27(10): 1642-1650.

Doumas, B.T.; W.A. Watson and H.G. Biggs ,1971. Albumin standards and the measurement of serum albumin with bromocresol green. Clin. Chim. Acta, 31: 87-96.

Duncan, D.B., 1955. Multiple range and multiple F tests. Biometrics, 11: 1-42.

Ferguson, N.S.; R.S. Gates; J.L. Taraba; A.H. Cantor; A.J. Pescatore ; M.L. Straw; M.J. Ford and D.J. Burnham, 1998. The effect of dietary protein and phosphorus on ammonia concentration and litter composition in broilers. Poultry Sci., 77: 10851093.
Fossati, P. and L. Prencipe ,1982. Serum triglycerides determined colorimetrically with an enzyme that produces hydrogen peroxide. Clin. Chem., 28: 2077-2080.

Frings, C.S and R.T. Dunn,1970. A colorimetric method for determination of total serum lipids based on the sulfo-phosphovanillin reaction. Amer. J. Clin. Pathol, 53: 89-91.

Gous, R. M., 2010. Nutritional limitations on growth and development in poultry. Livest. Sci. 130: 2532.

Greenwood, M. W. ; K. R. Cramer; R. S. Beyer; P. M. Clark and K. C. Behnke, 2005. Influence of feed form on estimated digestible lysine needs of male broilers from sixteen to thirty days of age. J. Appl. Poult. Res., 14: 130-135.

Kermanshahi, H.; N. Ziaei and M. Pilevar, 2011.Effect of dietary crude protein fluctuation on performance, blood parameters and nutrients retention in broiler chicken during starter period. Global Veterinaria, 6 (2): 162-167

Lemme, A. ; P. J. A. Wijtten; J. van Wichen ; A. Petri, and D. J. Langhout , 2006. Responses of male growing broilers to increasing levels of balanced protein offered as coarse mash or pellets of varying quality. Poult. Sci. 85: 721-730

Myers, G.L.; G.R. Cooper; L.O. Henderson; D.J. Hassemer and M. Kimberly,1994. Standardization of lipid and lipoprotein Measurements. In: Laboratory Measurement of Lipids Lipoproteins and Apolipoproteins, Rifai, N. and G.R. Warnick (Eds.). Washington, DC:AACC Press.

NRC ; National Research Council ,1994. Nutrient Rrequirements of Poultry. Ninth revised edition. National Academy Press, Washington, DC. USA.

Richards, M.P.,2003. Genetic regulation of feed intake and energy balance in poultry. Poultry Science; 82 (6): 907-916.

Reitman, S. and S. Frankel, 1957. A colorimetric method for the determination of serum glutamic oxaloacetic and glutamic pyruvic transaminases. Amer. J. Clin. Pathol., 28, 56-61.

Rosebrough, R. W.; J. P. Mcmurtry and R. VasilatosYounken,1999. Dietary Fat and Protein Interactions in the Broiler. Poultry Science, 78: 992-998

SAS, 1996. Statistical Analysis System. SAS ® User's Guide: Statistics SAS institute Inc., Carry, NC, USA.

Scott, T. A., 2002. Evaluation of lighting programs, diet density, and short-term use of mash as compared to crumbled starter to reduce incidence of sudden death syndrome in broiler chicks to 35 days of age. Can. J. Anim. Sci. 82: 375-383.

Trinder, P., 1969. Determination of glucose in blood using glucose oxidase with an alternative oxygen acceptor. Ann. Clin. Biochem., 6: 24-27. 


\section{تأثثر كثافة العناصر الغذائية وشكل العليقة على الأداء الإنتاجى ومكونات الدام لكتاكيت التشمين

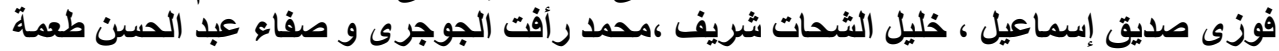 قسم إنتاج الدواجن - كلية الزراعة - جامعة المنصورة - مصريف}

أجريت هذه الدر اسة لتقييم تأثير كثافة العناصر الغذائية وشكل العليقة على الأداء الإنتاجى ومكونات الدم لكتاكيت التسمين. تم فى التى

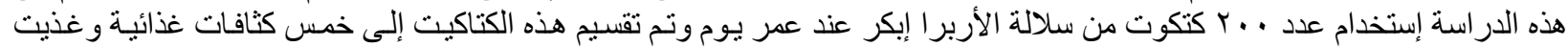

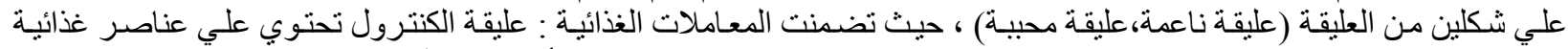

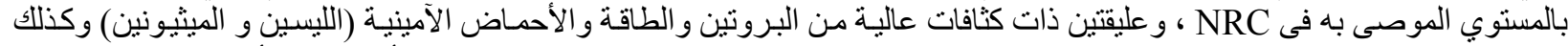

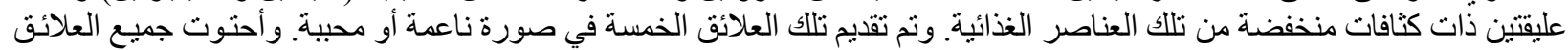

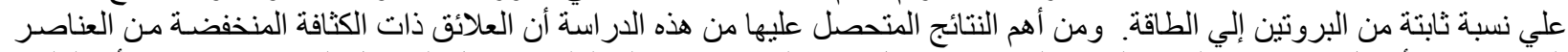

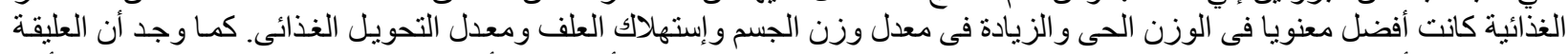

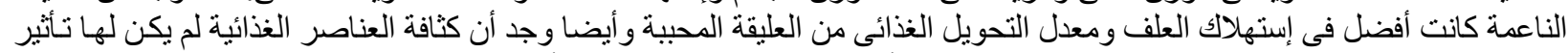

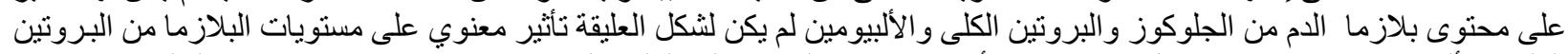

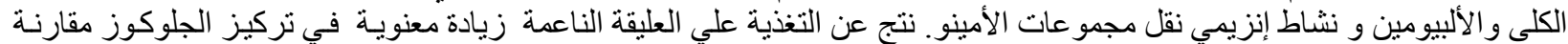

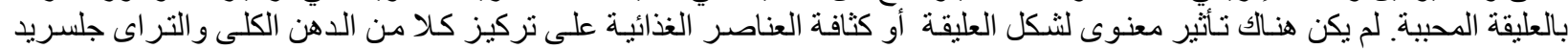

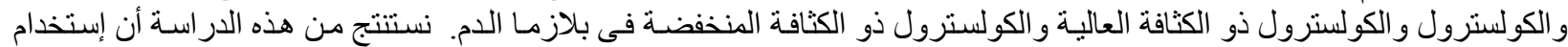

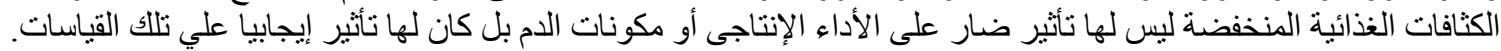

